\title{
Preterm Severe Neonatal Morbidity and Mortality in Breech Presentation Regarding the Onset Mode of Labor
}

Claire Guerini ( $\sim$ guerini.cl@gmail.com )

Hopital Robert Debre https://orcid.org/0000-0001-7253-4405

Korb Diane

Hopital Robert Debre

Sibony Olivier

Hopital Robert Debre

\section{Research Article}

Keywords: Induction of labor, spontaneous labor, cesarean section, breech, preterm, neonatal morbidity

Posted Date: March 15th, 2021

DOI: https://doi.org/10.21203/rs.3.rs-169934/v1

License: (c) (i) This work is licensed under a Creative Commons Attribution 4.0 International License.

Read Full License 


\section{Abstract}

\section{Purpose}

The objective was to assess neonatal severe morbidity in case of cervical ripening, in premature breech fetuses, comparatively at spontaneous labor.

\section{Methods}

This is a retrospective study conducted in a tertiary center.

Women with alive singleton breech between 28 and $36+6$ weeks of gestation were considered. We compared women with an unfavorable cervix, who had an indication to deliver, to women in spontaneous labor.

The primary outcome was a composite morbi-mortality criterion including perinatal death, traumatic event, 5-min Apgar < 4, moderate / severe encephalopathy, seizures, Intra Ventricular Hemorrhage grade 34 , necrotizing enterocolitis grade 2-3. The association between the onset of labor and severe neonatal morbidity was assessed by logistic regression model. A propensity score approach with inverse probability of treatment weighting was performed to control indication bias.

\section{Results}

We included 212 patients: 64 in the induced labor group and 136 in the spontaneous labor group. Labor was induced mostly for fetal growth restriction (34.4\%), oligoamnios (18.7\%) and pre-eclampsia (18.7\%). When induced labor, $45.3 \%$ of patients delivered vaginally, and $86 \%$ when spontaneous labor.

The rate of neonatal morbidity was similar in two groups ( $4.7 \%$ versus $5.2 \%, p=0.889)$. There was no association between the onset of labor and severe neonatal morbidity (OR 0.99, 95\% Cl 0.2-3.6)). After applying propensity scores, induction of labor was not associated with improved severe neonatal morbidity (OR 0.9, 95\% IC 0.4-2.5).

\section{Conclusion}

The onset mode of labor do not seem to have an effect on severe neonatal morbidity and mortality in preterm breech fetuses.

\section{Introduction}

Breech presentation occurs in $5 \%$ of deliveries and is more common preterm. Protective effect of cesarean section on the breech fetus is controversial, since publications showed divergent results on neonatal morbidity and mortality. However, vaginal delivery in breech presentation is still discussed. But it has been proved that it could be a safe option in selected patients regardless of gestational age. (1) (2) (3) (4) (5) (6) Routine cesarean section is not recommended for breech in spontaneous preterm labor. 
In France, $22.6 \%$ of labors are induced ones. (7) This is a common practice in cephalic presentation. The induction of labor in term breech presentation tends to have no impact on neonatal morbidity and mortality compared to spontaneous labor. (8) (9) (10) (11) (12) This has not been reviewed for pre-term breech presentation since international societies do not recommend this practice in routine since there are very few data on the subject. (13) (14)

The aim of this study was to assess neonatal severe morbidity and mortality in case of cervical ripening when unfavorable cervix, in premature breech fetuses, comparatively at spontaneous labor.

\section{Material And Methods}

This was a retrospective study, conducted in a tertiary universitary center in Paris, France.

We included all singleton living preterm breech deliveries between 28 and $36+6$ weeks of gestation. We excluded situations with medical contraindication to vaginal delivery (abnormal placenta implantation, multiple scared uterus, maternal disease, cephalopelvic disproportion) and fetal malformations. We collected data from 2000 to 2018.

We compared patients in spontaneous labor versus patients with a medical indication for the child to be born with an unfavorable cervix and thereby, needing induction of labor.

The maternity protocol did not include a systematic X-ray pelvimetry for breech even if preterm.

Considering patients with an unfavorable cervix, if a delivery was indicated but not emergent and could be delayed in a few days, induction of labor was considered with a close fetal and maternal monitoring in hospitalization. Cervical ripening was performed according to the local protocol (appendix 1).

During labor whatever the onset of labor, under continuous FHR monitoring, oxytocin infusion could be used if indicated. After two hours of failure to progress with oxytocin infusion a caesarean delivery was considered.

\subsection{Data collection}

Data were collected retrospectively from patients' electronic medical records and medical files. All patients were identified from the department's computer database. The entire medical file was computerized and was completed prospectively at each visit, at delivery, and during the postpartum period. All data were verified at the obstetrics staff meeting the day after the delivery. All maternal and pediatric records were also reviewed individually.

\subsection{Outcomes}

We defined as primary composite outcome a score of neonatal mortality and severe morbidity, including complications of prematurity and complications of breech delivery, adapted to composite criteria used in the Term Breech Trial and PREMODA study. (15) (16)This composite criterion included perinatal death 
(until 28 days of life), traumatic event during delivery (basal skull fracture, fracture of long bone or clavicle, brachial plexus injury), 5-min Apgar < 4, moderate or severe encephalopathy according Sarnat score, seizures within the first 24 hours, Intra Ventricular Hemorrhage grade 3 or 4 , necrotizing enterocolitis grade 2 or 3 .

Secondary neonatal less severe outcomes included arterial cord-blood $\mathrm{pH}$ at birth $<7.10$, intubation and ventilation $>24$ hours during the first three days, and early-onset bacterial infection (proved: clinical symptoms with bacteria in blood and/or cerebrospinal fluid ; probable : clinical or biological abnormalities).

Maternal morbidity was evaluated by the following events: post-partum hemorrhage (blood loss $\geq 500 \mathrm{cc}$ ) and its management, maternal need of secondary surgery and endometritis (defined by abdominal pain and fever, abnormal discharge, biological inflammatory syndrome and positive vaginal swab).

The following labor and delivery characteristics were also analyzed: modalities of induction, duration of labor, amniotic fluid characteristics, FHR anomalies during labor, use of oxytocin and mode of delivery.

\subsection{Statistical analyses}

First, we compared maternal, obstetric and neonatal characteristics between the two groups. Then we conducted univariate analyses to compare the two groups for the principal and secondary outcome measures. We used Student's t, Chi2, and Fisher's exact tests for the univariate analyses. To assess the association between the onset of labor and severe neonatal morbidity, we used a logistic regression model to estimate adjusted OR (OR) and $95 \% \mathrm{Cl}$.

To further control for indication bias related to confounding factors that might influence both the choice of the onset of labor and severe neonatal morbidity, we used a propensity score approach. The propensity score was defined as the probability of a spontaneous labor based on covariates. This analysis followed a three-step process. First, a propensity score was estimated for all pregnancies by a logistic regression model with the onset of labor as the dependent variable in relation to the baseline maternal, obstetric, neonatal, characteristics (nullipara, previous cesarean delivery, previous hypertensive condition, hospitalization for premature labor, premature rupture of the membranes, prenatal corticosteroids, suspected fetal growth restriction, gestational age at delivery, weight at delivery). Then, the inverse probability of treatment weighting (IPTW) based on estimated propensity scores was used to obtain a synthetic population in which the onset of labor was independent of measured baseline covariates, as confirmed by balance standardized differences. Imbalance was checked by propensity score distribution and calculation of standardized mean differences before and after applying the IPTW. Finally, the association of the onset of labor with severe neonatal morbi-mortality was quantified by OR and $95 \% \mathrm{Cls}$ estimated from a logistic regression model, without further adjustment.

The statistical analyses were performed using STATA software Version 13 (Stata Corp, College Station, TX, USA). 


\subsection{Ethics}

Under French regulations, this study was exempt from Institutional Review Board approval because it was an observational study using anonymized data from medical records. Women were informed that their records could be used for the evaluation of medical practices and were allowed to opt out of these studies. The medical database was approved by the National Data Protection Authority (Commission Nationale de l'Informatique et des Libertés, CNIL no. 293683).

\section{Results}

On the study period, 200 patients were included, $64(32 \%)$ in the induced labor group and $136(68 \%)$ in the spontaneous labor group. (Figure 1)

Most maternal characteristics were comparable except for parity. Patients in spontaneous labor were more often parous women.

Regarding pregnancy characteristics, women with induced labor suffered more from gestational hypertension and preeclampsia whereas women in spontaneous labor were hospitalized for premature labor or premature rupture of the membranes. Gestational age at delivery was slightly younger in women with spontaneous labor. (Table 1)

Induced labor was performed more often for fetal growth restriction (22/64 (34.4\%)), oligoamnios (12/64 $(18.7 \%))$ and preeclampsia (12/64 (18.7\%)). Among those women, $45.3 \%$ had a vaginal delivery, and $54.7 \%$ of women had a cesarean section, mostly for fetal heart rate anomalies $(26 / 35(74.3 \%))$.

Among women in spontaneous labor, $86 \%$ delivered vaginally and $14 \%$ needed an emergency cesarean section, for FHR anomalies in $63.2 \%$ cases.

The cervix dilation when a cesarean section occurred was lower in induced labor compared to spontaneous labor.

Comparing labor characteristics of the two groups, we can note that the induced labor group received more oxytocin during labor. (Table 2)

The rate of severe neonatal morbi-mortality was similar in two groups (4.7\% when induced labor vs $5.2 \%$ when spontaneous labor, $p=0.889$ ). (Table 3 ) There is not association between the onset of labor and severe neonatal morbi-mortality (OR $0.99,95 \% \mathrm{Cl} 0.2-3.6)$ ). After applying propensity scores and assigning IPTW, compared with spontaneous labor, induction of labor was not associated with improved severe neonatal morbi-mortality (OR $0.9,95 \%$ IC 0.4-2.5).

However, one neonatal death in the induced group and three in the spontaneous labor group occurred.

Considering the neonatal death in the induced labor group: labor was induced by prostaglandin at $36+6$ weeks of gestation for premature rupture of the membranes at $36+5 \mathrm{WG}$, there were no fetal heart rate 
abnormalities and no sign of infection during labor (labor duration: 4 hours). Vaginal delivery, performed by senior, was complicated with head entrapment needing use of forceps. There was no growth restriction ( $20^{\text {th }}$ percentile) and $\mathrm{pH}$ at delivery was 7,10 with Apgar score $2 / 0 / 0$. The neonate died at two days of life from multivisceral failure, autopsia did found visceral and cerebral anoxia and sign of amniotic inhalation.

The three neonatal death in the spontaneous group occurred in the delivery room. All mothers had been treated with prenatal corticosteroids.

Neonate one had a history of premature rupture of the membranes at $25 \mathrm{WG}$ and was delivered at the age of 28+5 WG by cesarean section at $5 \mathrm{~cm}$, performed for FHR anomalies. Amniotic fluid was clear, $\mathrm{pH}$ at delivery was 7.23 and Apgar score 1/0/0. Active resuscitation was performed with intra-tracheal administration of adrenaline, and decision was made to stop after 20 minutes.

Neonate two was delivered vaginally at 31+6 WG, spontaneous labor occurred after a history of PROM at 31 WG. Amniotic fluid was clear during labor with no suspicion of chorioamniotitis. It was a frank breech with need of Lovset and Mauriceau's manoeuvres at delivery. $\mathrm{pH}$ was 7.11, Apgar 3/1/1 and active resuscitation was started at birth, but stopped after 50 minutes.

Neonate three was also delivered vaginally at 31 WG after PROM with high suspicion of chorioamniotitis, fluid was meconial. Delivery was in complete breech with need of Lovset and Mauriceau's manoeuvres, $\mathrm{pH}$ at birth was 7.26, Apgar 1/1/1. Active resuscitation was stopped after 30 minutes.

Regarding maternal morbidity, there were no differences between the two groups, except from the need of transfusion, higher when induced labor $(p=0.01)$ while the rate of postpartum hemorrhage was not higher in this group. (Table 4)

\section{Discussion}

\subsection{Strengths}

To our knowledge, our study is among the first questioning the possibility of inducing labor in preterm breech fetuses.

There is a poor literature on this subject and it was suggested that cervical ripening was an independent factor of neonatal and maternal outcome. (17) (18)

We used as a primary outcome a composite criterion extracted from former publications and that we reviewed for the preterm fetuses population. (4) (19) (20)

We used propensity score analysis to minimize the likelihood of incorrectly attributing any risk of neonatal morbidity to onset of labor, which is an inherent difficulty in this study. 


\subsection{Weakness}

Nevertheless, we have a small sample of patients and we collected data retrospectively. That could conduct to lack of statistical power.

Moreover, comparing those two populations (induced and spontaneous labor group) could be discussed. In fact, the context of birth is different and could influence neonatal outcomes.

They seem to be differences in neonatal outcomes regarding the cause of prematurity. Intra-uterine environment could participate in increasing certain types of complications as intra ventricular hemorrhage and neonatal sepsis. (21)

Thus, pre-eclampsia seems to appear as an adverse factor concerning short-term neonatal outcome but the mechanism is still unknown. (22) (23)

Birth weight and especially fetal growth restriction is also correlated with neonatal outcome. Several research correlate FGR with increased morbidity and mortality in preterm fetuses. (24) (25) (26)

\subsection{Interpretation}

Inducing labor is a common practice when cephalic presentation.

Several studies were interested in comparing neonatal and maternal outcomes between induced and spontaneous labor in term breech fetuses. They showed no differences between those two onsets of labor.

International guidelines do mention as an option planned vaginal delivery. (13) (27) (28) (29)

But few people were interested in this same topic for preterm breech fetuses.

In our study the rate of vaginal delivery after induction is around $45 \%$, which is fewer than the rate observed in literature when term breech fetuses (58\%-65\%). (10) (11) (30)

There were no differences on neonatal morbidity and mortality between induced and spontaneous labor while the induced labor population tends to be more fragile (fetal growth restriction and pre-eclampsia being the more frequent indication of birth). Neonatal death was not related with the onset mode of labor.

\section{Conclusion}

A strategy of induction of labor in case of preterm breech among women with unfavorable cervix allows a vaginal delivery for more than $40 \%$ of patients. We found no difference on severe neonatal mortality and morbidity between induced and spontaneous onset of labor.

Inducing labor could be discussed in preterm breech fetuses in selected patients with need to deliver within a few days. 


\section{Declarations}

All authors agree for submission.

\section{Authors contribution}

Guerini Claire : Data collection and management, Manuscript writing

Korb Diane : Data analysis, Manuscript editind

Sibony Olivier : Manuscript editing

\section{Conflicts of interest}

The authors report no conflict of interest.

\section{References}

1. Alfirevic Z, Milan SJ, Livio S. Caesarean section versus vaginal delivery for preterm birth in singletons. Cochrane Pregnancy and Childbirth Group, éditeur. Cochrane Database Syst Rev [Internet]. 12 sept 2013 [cité 22 mai 2020]; Disponible sur: http://doi.wiley.com/10.1002/14651858.CD000078.pub3

2. Louwen F, Leuchter L, Reitter A (2012) Beckenendlagengeburt - mehr als Sectio vs. Spontangeburt Z Für Geburtshilfe Neonatol août 216(04):191-194

3. Toivonen E, Palomäki O, Huhtala H, Uotila J (2012) Selective vaginal breech delivery at term - still an option: Vaginal breech delivery at term. Acta Obstet Gynecol Scand oct 91(10):1177-1183

4. Goffinet F, Carayol M, Foidart J-M, Alexander S, Uzan S, Subtil D et al (2006) Is planned vaginal delivery for breech presentation at term still an option? Results of an observational prospective survey in France and Belgium. Am J Obstet Gynecol avr 194(4):1002-1011

5. Kotaska A, Menticoglou S, Gagnon R, Farine D, Basso M, Bos H et al (2009) Vaginal delivery of breech presentation. Int J Gynecol Obstet 107(2):169-176

6. Bergenhenegouwen LA, Meertens LJE, Schaaf J, Nijhuis JG, Mol BW, Kok M et al (2014) Vaginal delivery versus caesarean section in preterm breech delivery: a systematic review. Eur $\mathrm{J}$ Obstet Gynecol Reprod Biol janv 172:1-6

7. ENP2016_rapport_complet (1).pdf

8. Burgos J, Arana I, Garitano I, Rodríguez L, Cobos P, Osuna C et al. Induction of labor in breech presentation at term: a retrospective cohort study. J Perinat Med [Internet]. 1 janv 2017 [cité 22 mars 2020];45(3). Disponible sur: https://www.degruyter.com/view/j/jpme.ahead-of-print/jpm-20150426/jpm-2015-0426.xml

9. Jarniat A, Eluard V, Martz O, Calmelet P, Calmelet A, Dellinger $P$ et al (2017) Induced labour at term and breech presentation: Experience of a level IIB French maternity. J Gynecol Obstet Hum Reprod 
sept 46(7):597-600

10. Rojansky N, Tsafrir A, Ophir E, Ezra Y (2001) Induction of labor in breech presentation. Int J Gynecol Obstet août 74(2):151-156

11. Macharey G, Ulander V-M, Heinonen S, Kostev K, Nuutila M, Väisänen-Tommiska M (2016) Induction of labor in breech presentations at term: a retrospective observational study. Arch Gynecol Obstet mars 293(3):549-555

12. Sun W, Liu F, Liu S, Gratton S-M, El-Chaar D, Wen SW et al (2018) Comparison of outcomes between induction of labor and spontaneous labor for term breech - A systemic review and meta analysis. Eur J Obstet Gynecol Reprod Biol mars 222:155-160

13. RPC-CNGOF-presentation-siege.pdf

14. Management of Breech Presentation (2017) Green-top Guideline No. 20b. BJOG Int J Obstet Gynaecol juin 124(7):e151-e177

15. Hannah et al. - 2000 - Planned caesarean section versus planned vaginal b.pdf

16. Goffinet et al. - 2006 - Is planned vaginal delivery for breech presentatio.pdf

17. Marzouk $P$, Arnaud E, Oury J-F, Sibony $O$ (2011) Induction du travail et présentation du siège: expérience de la maternité de l'hôpital Robert-Debré. Paris J Gynécologie Obstétrique Biol Reprod nov 40(7):668-674

18. Kuper SG, Sievert RA, Steele R, Biggio JR, Tita AT, Harper LM. Maternal and Neonatal Outcomes in Indicated Preterm Births Based on the Intended Mode of Delivery: Obstet Gynecol. nov 2017;130(5):1143-51

19. Hannah ME, Hannah WJ, Hewson SA, Hodnett ED, Saigal S, Willan AR (2000) Planned caesarean section versus planned vaginal birth for breech presentation at term: a randomised multicentre trial. THE LANCET 356:9

20. Gaillard T, Girault A, Alexander S, Goffinet F, Le Ray C (2019) Is induction of labor a reasonable option for breech presentation? Acta Obstet Gynecol Scand juill 98(7):885-893

21. Nayeri UA, Buhimschi CS, Zhao G, Buhimschi IA, Bhandari V. Components of the antepartum, intrapartum, and postpartum exposome impact on distinct short-term adverse neonatal outcomes of premature infants: A prospective cohort study. Szyld E, éditeur. PLOS ONE. 5 déc 2018;13(12):e0207298

22. Jelin AC, Kaimal AJ, Kuzniewicz M, Little SE, Cheng YW, Caughey AB (2012) Preterm preeclampsia: 32 to 37 weeks gestation. J Matern Fetal Neonatal Med nov 25(11):2198-2201

23. Bastek J, Srinivas S, Sammel M, Elovitz M (2010) Do Neonatal Outcomes Differ Depending on the Cause of Preterm Birth? A Comparison between Spontaneous Birth and latrogenic Delivery for Preeclampsia. Am J Perinatol févr 27(02):163-169

24. Delorme P, Goffinet F, Ancel P-Y, Foix-L'Hélias L, Langer B, Lebeaux C et al (2016) Cause of Preterm Birth as a Prognostic Factor for Mortality. Obstet Gynecol janv 127(1):40-48 
25. Garite TJ, Clark R, Thorp JA (2004) Intrauterine growth restriction increases morbidity and mortality among premature neonates. Am J Obstet Gynecol août 191(2):481-487

26. Longo S, Bollani L, Decembrino L, Di Comite A, Angelini M, Stronati M (2013) Short-term and longterm sequelae in intrauterine growth retardation (IUGR). J Matern Fetal Neonatal Med févr 26(3):222-225

27. Mode of Term Singleton Breech Delivery.pdf

28. Management of Breech Presentation (2017) Green-top Guideline No. 20b. BJOG Int J Obstet Gynaecol juin 124(7):e151-e177

29. Kotaska A, Menticoglou S (2019) No 384 - Prise en charge de la présentation du siège du fœtus à terme. J Obstet Gynaecol Can août 41(8):1206-1220

30. Breton A, Gueudry P, Branger B, Le Baccon F-A, Thubert T, Arthuis C et al (2018) Comparaison du pronostic obstétrical des tentatives d'accouchement par le siège: travail spontané versus déclenchement. Gynécologie Obstétrique Fertil Sénologie sept 46(9):632-638

\section{Tables}

Table 1: Maternal and pregnancy characteristics 


\begin{tabular}{|c|c|c|c|}
\hline & Induced labor & Spontaneous labor & $\mathbf{P}$ \\
\hline & $N=64$ & $N=136$ & \\
\hline & $\mathrm{n}(\%)$ & $\mathrm{n}(\%)$ & \\
\hline Maternal age $(y$, mean $\pm s d)$ & $32.4 \pm 5.5$ & $31.9 \pm 5.7$ & 0.52 \\
\hline$<25$ & $7(10.9)$ & $16(11.8)$ & \multirow[t]{4}{*}{0.644} \\
\hline [25-29] & $13(20.3)$ & $34(25)$ & \\
\hline [30-34] & $21(32.8)$ & $49(36)$ & \\
\hline$\geq 35$ & $23(36)$ & $37(27.2)$ & \\
\hline Body Mass Index ( mean \pm sd) & $23.6 \pm 5.3$ & $23.4 \pm 5.6$ & 0.82 \\
\hline$<18.5$ & $31(54.4)$ & $58(51.8)$ & \multirow[t]{4}{*}{0.91} \\
\hline$[18.5-24.9]$ & $7(12.3)$ & $16(14.3)$ & \\
\hline$[25-29.9]$ & $11(19.3)$ & $25(22.3)$ & \\
\hline$\geq 30$ & $8(14)$ & $13(11.6)$ & \\
\hline Smoker & $1(1.6)$ & $5(3.7)$ & 0.41 \\
\hline Parity & & & 0.165 \\
\hline Nullipara & $34(53.1)$ & $58(42.6)$ & \multirow[t]{5}{*}{0.02} \\
\hline Parous & $30(46.9)$ & $78(57.4)$ & \\
\hline 1 & $12(18.8)$ & $48(35.3)$ & \\
\hline 2 & $5(7.8)$ & $17(12.5)$ & \\
\hline$\geq 3$ & $13(20.3)$ & $13(9.6)$ & \\
\hline Previous cesarean delivery & $11(17.2)$ & $11(8.1)$ & 0.055 \\
\hline \multicolumn{4}{|l|}{ Diabetes } \\
\hline Type 1 diabetes & $1(1.6)$ & $1(0.7)$ & 0.58 \\
\hline Type 2 diabetes & $1(1.6)$ & 0 & 0.14 \\
\hline Previous hypertensive condition & $2(3.1)$ & $4(2.9)$ & 0.94 \\
\hline \multicolumn{4}{|l|}{ Pregnancy characteristics } \\
\hline Diabetes & $7(10.9)$ & $10(7.3)$ & 0.396 \\
\hline
\end{tabular}




\begin{tabular}{|c|c|c|c|}
\hline Gestational diabetes (diet) & $3(4.7)$ & $7(5.2)$ & 0.89 \\
\hline Gestational diabetes (insulin) & $4(6.3)$ & $3(2.2)$ & 0.279 \\
\hline Gestational hypertension & $17(26.6)$ & $2(1.5)$ & 0.000 \\
\hline Preeclampsia & $18(23.1)$ & $1(0.74)$ & 0.000 \\
\hline Mild pre-eclampsia* & $5(7.8)$ & $1(0.74)$ & 0.006 \\
\hline Severe pre-eclampsia** & $13(20.3)$ & 0 & 0.000 \\
\hline Eclampsia & 0 & $1(0.74)^{\star \star \star}$ & 0.454 \\
\hline retroplacental hematoma ${ }^{\star \star \star \star}$ & $2(3.1)$ & $3(2.2)$ & 0.698 \\
\hline Hospitalisation for premature labour & $9(14.1)$ & $59(43.4)$ & 0.000 \\
\hline Suspected fetal growth restriction $<10$ th percentile & $32(50.0)$ & $9(6.6)$ & 0.000 \\
\hline Premature rupture of the membranes & $22(34.4)$ & $89(66.4)$ & 0.000 \\
\hline Chorioamniotitis & $8(12.5)$ & $13(9.6)$ & 0.53 \\
\hline Prenatal corticosteroids & $34(53.1)$ & $83(61)$ & 0.29 \\
\hline 1 (2 injections) & $30(88.2)$ & $78(94)$ & 0.29 \\
\hline 2 (4 injections) & $4(11.8)$ & $5(6)$ & \\
\hline Gestational age at delivery (GW, mean \pm sd) & $34 \pm 1.9$ & $33 \pm 2.7$ & 0.004 \\
\hline$[28-32[$ & $7(10.9)$ & $47(34.6)$ & 0.002 \\
\hline$[32-34[$ & $13(20.3)$ & $24(17.6)$ & \\
\hline$[34-37[$ & $44(68.8)$ & $65(47.8)$ & \\
\hline \multicolumn{4}{|c|}{$\begin{array}{l}\text { *Mild to moderate high blood pressure, } 140-159 \mathrm{~mm} \text { Hg systolic or } 90-159 \mathrm{~mm} \text { Hg diastolic and } \\
\text { proteinuria } 0,3-3 \mathrm{~g} / \mathrm{L}\end{array}$} \\
\hline \multicolumn{4}{|c|}{$\begin{array}{l}\star \star H i g h \text { blood pressure greater than or equal to } 160 \mathrm{~mm} \mathrm{Hg} \text { systolic or greater than or equal to } 110 \\
\mathrm{~mm} \text { Hg diastolic, proteinuria }>3 \mathrm{~g} / \mathrm{L} \text {, oliguria, hepatic dysfunction, fœetal growth restriction }\end{array}$} \\
\hline \multicolumn{4}{|l|}{ 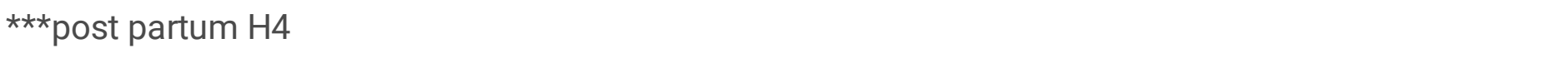 } \\
\hline$\star \star \star \star \star$ anatomopathological examination & & & \\
\hline
\end{tabular}


Table 2: Mode of delivery, indications of cesarean section and induction of labor

Page $13 / 18$ 


\begin{tabular}{|c|c|c|c|}
\hline & $\begin{array}{l}\text { Politics of induced } \\
\text { labor }\end{array}$ & $\begin{array}{l}\text { Spontaneous } \\
\text { labor }\end{array}$ & $\mathbf{P}$ \\
\hline & $N=64$ & $N=136$ & \\
\hline & $\mathrm{n}(\%)$ & $\mathrm{n}(\%)$ & \\
\hline \multicolumn{4}{|l|}{ Delivery mode } \\
\hline Vaginal delivery & $29(45.3)$ & $117(86)$ & \\
\hline Cesarean before or during labor & $35(54.7)$ & $19(14)$ & \\
\hline Indication of induced labour & \multicolumn{3}{|l|}{$N=64$} \\
\hline Fœtal growth restriction & \multicolumn{3}{|l|}{$22(34.4)$} \\
\hline Oligoanamnios & \multicolumn{3}{|l|}{$12(18.7)$} \\
\hline Pre-eclampsia & \multicolumn{3}{|l|}{$12(18.7)$} \\
\hline Chorioamniotitis & \multicolumn{3}{|l|}{$7(10.9)$} \\
\hline Premature rupture of the membranes & \multicolumn{3}{|l|}{$6(9.4)$} \\
\hline FHR anomalies & \multicolumn{3}{|l|}{$4(6.3)$} \\
\hline Protéinuria & \multicolumn{3}{|l|}{$1(1.6)$} \\
\hline Indication of cesarean & $N=35$ & $N=19$ & \\
\hline FHR anomalies & $26(74.3)$ & $12(63.2)$ & \\
\hline Fœtal growth restriction & $2(5.7)$ & 0 & \\
\hline HELLP & $1(2.9)$ & 0 & \\
\hline Pre-eclampsia & $1(2.9)$ & 0 & \\
\hline cord prolaps & $1(2.9)$ & $2(10.5)$ & \\
\hline failure to progress & $2(5.7)$ & $2(10.5)$ & \\
\hline other cause & $2(5.7)$ & 0 & \\
\hline no engagement of the fetal head & 0 & $3(15.8)$ & \\
\hline $\begin{array}{l}\text { Cervix dilatation when cesarean section }(y, \\
\text { mean } \pm s d)\end{array}$ & $2 \pm 2$ & $6 \pm 2$ & 0.000 \\
\hline \multirow[t]{2}{*}{$\begin{array}{l}\text { Length : delivery room until delivery (min) }(y \text {, } \\
\text { mean } \pm \text { sd) }\end{array}$} & $314 \pm 252$ & $242 \pm 175$ & 0.034 \\
\hline & $N=46$ & $N=136$ & \\
\hline
\end{tabular}




$\left|\begin{array}{|llll|}\text { Cesarean before labor excluded } & & & \\ \text { Epidural anesthesia } & 36(78.3) & 102(75) & 0.655 \\ \text { Clear amniotic fluid } & 35(76.1) & 118(86.8) & 0.162 \\ \text { Maternal fever } & 2(4.4) & 5(3.7) & 0.84 \\ \text { Tachycardia } & 11(23.9) & 15(11) & 0.03 \\ \text { FHR anomalies during labor } & 28(60.9) & 93(69) & 0.318 \\ \text { antibiotics during labor } & 41(89.1) & 115(84.6) & 0.44 \\ \text { Oxytocin during labor } & 31(67.4) & 63(46.3) & 0.013\end{array}\right|$

Table 3: Neonatal morbidity and mortality 


\begin{tabular}{|c|c|c|c|}
\hline & Induced labor & Spontaneous labor & $\mathbf{P}$ \\
\hline & $N=64$ & $N=136$ & \\
\hline & $\mathrm{n}(\%)$ & $\mathrm{n}(\%)$ & \\
\hline Composite neonatal morbidity & $3(4.7)$ & $7(5.2)$ & 0.889 \\
\hline Neonatal deaths & $1(1.56)$ & $3(2.2)$ & 0.76 \\
\hline Long bones fracture & 0 & $1(0.74)$ & 0.492 \\
\hline Brachial plexus injuries & 0 & 0 & \\
\hline 5-min Apgar $<4$ & $3(4.7)$ & $3(2.2)$ & 0.337 \\
\hline Moderate or severe encephalopathy & $1(1.56)$ & 0 & 0.144 \\
\hline Convulsions & 0 & 0 & \\
\hline IVH 3-4 & $1(1.56)$ & $1(0.74)$ & 0.583 \\
\hline Necroziting enterocolitis 2-3 & 0 & $2(1.47)$ & 0.33 \\
\hline \multicolumn{4}{|l|}{$\mathrm{pH}$} \\
\hline $\mathrm{pH} £ 7,10$ & 4 & 3 & 0.147 \\
\hline \multicolumn{4}{|l|}{ Ventilation } \\
\hline Intubation & $15(23.4)$ & $23(16.9)$ & 0.27 \\
\hline Ventilation $>24 \mathrm{~h}$ in the 721 st hours & $25(39.1)$ & $49(36)$ & 0.68 \\
\hline pneumothorax & 0 & $1(0.74)$ & 0.492 \\
\hline Early-onset bacterial infection & $4(6.25)$ & $12(8.8)$ & 0.531 \\
\hline Sex & & & 0.23 \\
\hline Male & $35(54.7)$ & $62(45.6)$ & \\
\hline Female & $29(45.3)$ & $74(54.4)$ & \\
\hline Birth weight $(y$, mean $\pm s d)$ & $1889 \pm 534$ & $2054 \pm 575$ & 0.054 \\
\hline$<1000$ & $1(1.56)$ & $1(0.7)$ & 0.319 \\
\hline$[1000-1500[$ & $19(29.7)$ & $28(20.6)$ & \\
\hline$[1500-2000[$ & $19(29.7)$ & $33(24.3)$ & \\
\hline [2000-2500[ & 14 (21.9) & 40 (29.4) & \\
\hline
\end{tabular}




\begin{tabular}{|llll|}
$\geq 2500$ & $11(17.2)$ & $34(25)$ & \\
\hline Birth weight $<$ 10th percentile & $32(50)$ & $5(3.7)$ & 0.000 \\
\hline
\end{tabular}

Table 4: Maternal morbidity

\begin{tabular}{|c|c|c|c|}
\hline & Induced labor & Spontaneous labor & $\mathbf{P}$ \\
\hline & $N=64$ & $N=136$ & \\
\hline & $\mathrm{n}(\%)$ & $\mathrm{n}(\%)$ & \\
\hline \multicolumn{4}{|l|}{ Maternal morbidity } \\
\hline Maternal death & 0 & 0 & \\
\hline Uterine rupture & 0 & 0 & \\
\hline accreta & 0 & $2^{*}$ & \\
\hline Postpartum hemorrhage $>=500 \mathrm{cc}$ & $2(3.1)$ & $5(3.7)$ & 0.843 \\
\hline Transfusion & $3(4.7)$ & 0 & 0.011 \\
\hline Uterine padding & 0 & 0 & \\
\hline Hysterectomy & 0 & 0 & \\
\hline Sulprostone & $2(3.13)$ & $4(2.9)$ & 0.943 \\
\hline Uterine tamponade & 0 & 0 & \\
\hline Secondary surgery & 0 & 0 & \\
\hline Endometritis & 0 & $1(0.74)$ & 0.492 \\
\hline
\end{tabular}

*unknown, discovered during delivery and confirmed by the anatomopathological examination

\section{Figures}




\section{Singleton, alive preterm breech, 28 - 36+6 WG}

\begin{tabular}{|c|c|c|}
\hline $\begin{array}{l}\text { Induced labor } \\
\qquad \mathrm{N}=456\end{array}$ & & $\begin{array}{c}\text { Spontaneous labor } \\
\qquad \mathrm{N}=338 \\
\end{array}$ \\
\hline $\begin{array}{c}\mathrm{n}= \\
358 \\
30 \\
4\end{array}$ & $\begin{array}{l}\text { Exclusion } \\
\text { Contra-indication to VD* } \\
\text { Fœtal malformations } \\
\text { Missing datas }\end{array}$ & $\begin{array}{c}\mathrm{n}= \\
149 \\
24 \\
29\end{array}$ \\
\hline $\begin{array}{l}\text { Induced labor } \\
\qquad N=64\end{array}$ & & $\begin{array}{c}\text { Spontaneous labor } \\
N=136\end{array}$ \\
\hline
\end{tabular}

- abnormal placenta implantation, multiple scared uterus, maternal disease, cepbalopelvic disproportion, emergency situations (severe foetal heart rate abnomalities, severe pre-eclampsis, HEL.L.P, important bleeding, cord pocolaps)

\section{Figure 1}

Flow Chart 